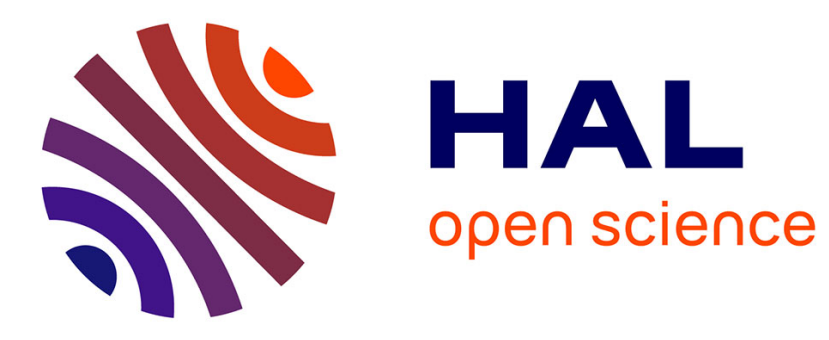

\title{
In Situ FTIR Reactor for Monitoring Gas-Phase Products during a (Photo)catalytic Reaction in the Liquid Phase
}

Igor Telegeiev, Oumaima Thili, Adrien Lanel, Philippe Bazin, Yoann Levaque, Christian Fernandez, Mohamad El-Roz

\section{To cite this version:}

Igor Telegeiev, Oumaima Thili, Adrien Lanel, Philippe Bazin, Yoann Levaque, et al.. In Situ FTIR Reactor for Monitoring Gas-Phase Products during a (Photo)catalytic Reaction in the Liquid Phase. Analytical Chemistry, 2018, 90 (24), pp.14586-14592. 10.1021/acs.analchem.8b04754 . hal-02400509

\section{HAL Id: hal-02400509 \\ https://hal.science/hal-02400509}

Submitted on 5 Oct 2021

HAL is a multi-disciplinary open access archive for the deposit and dissemination of scientific research documents, whether they are published or not. The documents may come from teaching and research institutions in France or abroad, or from public or private research centers.
L'archive ouverte pluridisciplinaire HAL, est destinée au dépôt et à la diffusion de documents scientifiques de niveau recherche, publiés ou non, émanant des établissements d'enseignement et de recherche français ou étrangers, des laboratoires publics ou privés. 


\title{
In situFTIR reactor for monitoring gas phase products during a (photo)catalytic reaction in the liquid phase
}

\author{
Igor Telegeiev, Oumaima Thili, Adrien Lanel, Philippe Bazin, Yoann Levaque, Christian Fernandez, \\ Mohamad El-Roz*
}

Normandie Univ, Ensicaen, Unicaen, CNRS, Laboratoire Catalyse et Spectrochimie, 14000 Caen, France

\begin{abstract}
Various catalytic and photocatalytic reactions in the liquid phase give rise to gas products. Therefore, the identification and quantification of these products are of high importance and even essential for some reactions. In this communication, a new in situ FTIR reactor is designed and used for analyzing the gas headspace of a (photo)catalytic reaction in solution. It allows the identification and quantification of the gas products of a liquid reaction under operating conditions and in real time. The new reactor has been tested in three representative photocatalytic reactions widely studied as model reactions in the liquid phase, i.e., i) decomposition of formic acid, ii) oxidation of Methylene Blue and iii) reduction of $\mathrm{CO}_{2}$. The validity of the results has been confirmed by analyzing the headspace at the end of the reaction using GC. The new reactor opens the possibility to follow on-line the (photo)catalyst activity. This is useful for ensuring the stability of the catalyst and studying the evolution of the selectivity during the reaction. The nondestructive behavior of the FTIR technique allows its coupling with other techniques for obtaining complementary results. The new reactor setup is easy to handle, to ship, and is very efficient which make it very suitable for performing fast and/or preliminary studies.
\end{abstract}

\section{INTRODUCTION}

An increasing attention has been recently given to the liquid phase photocatalytic and catalytic reactions. Many of these systems include a solid-liquid interface or solid-liquid-gas interfaces that give rise to gas products. These heterogeneous catalyzed multi-phase systems are commonly found in $\mathrm{CO}_{2}$ photoreduction, ${ }^{1,2}$ water splitting, ${ }^{3-7}$ and other processes for total oxidation and/or transformation of hazardous chemical wastes for water purification. ${ }^{8-10}$ In addition, the conversion of biomass, aerobic fermentation and selective aerobic oxidation become of high importance in solid-liquid-gas reactions. ${ }^{11,12}$ Therefore, the development of techniques able to monitor the gas phase products of heterogeneous liquid reactions under working conditions is highly desirable. ${ }^{13-15}$

Off-line analytical techniques, such as gas chromatography (GC) and mass spectrometry (MS) are conventionally, used for analyzing and quantifying the effluent gas products. In such a procedure, the analyzed samples have to be taken from the reaction medium and studied separately or with an on-line analyzer. Nevertheless, GC-MS analysis is rather expensive and a time-consuming process.

In situ FTIR spectroscopy found to be very attractive for analyzing gas phase products of solid-gas catalytic reactions. ${ }^{16-18}$ In the transmission mode, it gives a quantitative information on the evolution of the gas phase products in real time. The nondestructive behavior of the FTIR technique allows its coupling with other analytic techniques. ${ }^{19-21}$

However, up to date, the use of the in situ mode FTIR technique is mainly limited to the solid/gas phase reactions and/or for monitoring the adsorbed species on the photocatalytic surface. ${ }^{22-24}$ Herein, we report a new in situ FTIR reactor for a realtime analysis of the gas products during a liquid photocatalytic reaction, under operating conditions. It is mainly dedicated for the studies of homogeneous and heterogeneous catalytic and photocatalytic reactions of gas and liquid dissolved reactants. The new reactor (Scheme 1) is compact and easily detachable (easy to be cleaned and installed). It is sealed and offers the possibility to work under control atmosphere and at a relatively high pressure (from atmospheric pressure up to 5 bars). The new in situ reactor can be used in batch with the possibility to be used as a flow reactor. Its configuration fits well for studying photocatalytic and thermal catalytic reaction under soft conditions ( 298 to $353 \mathrm{~K}$; depending of the reaction medium). The universal connectors (inlet and outlet) used in the fabrication of the reactor offers the possibility to add different accessories (e.g., gas trap at controlled temperature; vacuum connector; inlet and outlet gas connectors, etc.).

In this work, three well-known photocatalytic reactions have been performed to highlight the performance and the main advantages of the new setup: i) photocatalytic decomposition of formic acid on $\mathrm{TiO}_{2}$; ii) photodegradation of Methylene Blue on $\mathrm{TiO}_{2}$; iii) and $\mathrm{CO}_{2}$ photoreduction on $\mathrm{Re}($ bpy $)(\mathrm{CO})_{3} \mathrm{Cl}$. After the calibration of the reactor with the possible gas products, the concentration profiles obtained by FTIR spectroscopy were compared and confirmed by single point off-line GC analysis at the end of the reaction. The error has been calculated by performing each reaction at least twice.

\section{EXPERIMENTAL}

\subsection{In situ FTIR reactor}

The new reactor is presented in Scheme 1 and Scheme $\mathrm{S} 1$ in the real dimensions. The reactor is made from glass and equipped with two gas inlet and outlet, perpendicular to the tubes ensuring the FTIR beam pathway through $\mathrm{CaF}_{2}$ windows. 
The FTIR tubes are slightly tilted to prevent the solvent condensation and accumulation. The UV-visible irradiation is ensured from the top through a removable quartz window. The quartz and $\mathrm{CaF}_{2}$ widows are attached to the reactor with screw fittings and the tightness is obtained by adapted Teflon O-rings. The total internal volume of the reactor is $160 \pm 5 \mathrm{~mL}$ and can be filled with 10 to $50 \mathrm{~mL}$ of the solution. The design allowed an easy opening and closing of the reactor, therefore, an easy clean after each experiment. The purge of the reactor is ensured by the mass flow controller system. The system allows operating as a batch or a continuous flow reactor due to its different possible accessories that can be connected to the reactor (Scheme $\mathrm{S} 1$ ). It should be noted that many optimization and reactors have been made before obtaining the final design presented here. This design solves the problem previously encountered and related with the sealing, condensation of the solvent, deformation of the O-ring (when organic solvents, e.g. acetonitrile, are used), irradiation reproducibility, etc.

In this study, the UV-visible irradiation was carried out using a UV-light guide (A10014-50-0110) mounted at the top of the IR cell and connected to a polychromatic light of Xe-Hg lamp (for UV irradiation) or Xe lamp (for visible irradiation) (LC8 spot light Hamamatsu, L10852, 200 W). Monochromatic irradiation was performed by using a band pass filter at $365 \mathrm{~nm}$ (irradiance around $15 \mathrm{~mW} / \mathrm{cm}^{2}$ ) or pass high filter for $\lambda>390$ $\mathrm{nm}$ (irradiance around $20 \mathrm{~mW} / \mathrm{cm}^{2}$ ).

All IR spectrum measurements with the in situ FTIR reactor were monitored in real time with 2 to $5 \mathrm{~min} / \mathrm{spectrum}$ of time resolution. IR spectra of the reactor headspace were recorded using Nicolet 6700 IR spectrometer (Thermo Fisher Scientific) equipped with an MCT detector.

In the batch configuration, the cell can be heated at the desired temperature (298 to $353 \mathrm{~K}$ ) with a removable resistance and the temperature is controlled by a thermocouple (inserted via a septum). All photocatalytic tests presented in this work were performed at room temperature (298-303 K).

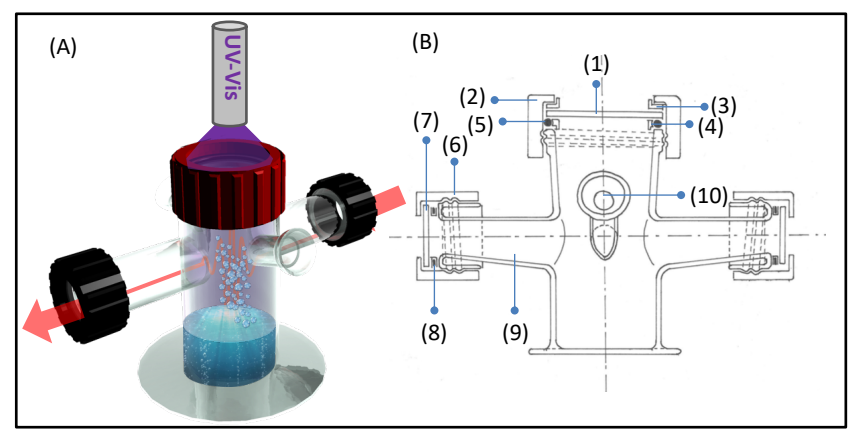

Scheme 1. (A) The new in situ FTIR reactor used in this work for monitoring the gas headspace of a photocatalytic reaction in the liquid phase. (B) Industrial scheme of the reactor from the side view:(1) quartz window; (2) quartz window screw; (3) plastic-ring fitting of the quartz window; (4) Inox O-ring holder; (5) O-ring; (6) Screws of the $\mathrm{CaF}_{2}$ IR windows; (7) $\mathrm{CaF}_{2} \mathrm{IR}$ windows; (8) Teflon O-ring; (9) IR beam pathway; (10) Gas inlet/outlet of the reactor. More details on the reactor and the reactor's accessories are reported in Scheme S1 in the supporting information.

\subsection{Gas chromatographic analysis GC}

Off-line $\mathrm{GC}$ analysis of $\mathrm{H}_{2}, \mathrm{CO}_{2}$ and $\mathrm{CO}$ were conducted using Thermo Scientific Trace 1310 with a Thermal conductivity detector (GC-TCD for TRACE 1300 GC Series, Thermo Scientific), and equipped with a MolSive5 A column $(30 \mathrm{~m} \times 0.53$ $\mathrm{mm}, 50 \mu \mathrm{m})$. For this purpose, injections $(1 \mathrm{~mL})$ of gas headspace were made in the $\mathrm{GC}$ and the resulting peak areas were converted into concentrations by using a calibration with the corresponding standard gases (operating conditions: carrier gas, $\mathrm{He}$ (for $\mathrm{H}_{2}$ and $\mathrm{CO}$ ) and $\mathrm{N}_{2}$ for $\mathrm{CO}_{2}$; split flow rate $=60$ $\mathrm{mL} / \mathrm{min}$; split ratio $=1 / 12$; inlet temperature $=423 \mathrm{~K}$; column temperature $393 \mathrm{~K}$ (for $\mathrm{H}_{2}$ and $\mathrm{CO}$ ) and $523 \mathrm{~K}$ (for $\mathrm{CO}_{2}$ )).

\subsection{Materials}

The following chemicals were obtained from commercial sources (Sigma Aldrich) and used without further purification: 2,2'-Bipyridine(bpy), pentacarbonyl-chlororhenium(I), Formic acid ( $\mathrm{HCOOH}, \leq 98 \%$ purity), Acetonitrile (ACN, 99.8\% purity), Triethanolamine (TEOA, $\geq 99.0 \%$ purity), and Methylene Blue (MB, $\geq 95 \%$ purity).

The photocatalytic decomposition of formic acid (FAc) and the photodegradation of $\mathrm{MB}$ were performed by using the commercially available $\mathrm{TiO}_{2} \mathrm{P} 25$ as photocatalyst (Evonik P25, 51 $\mathrm{m}^{2} / \mathrm{g}$ ).

The $\mathrm{CO}_{2}$ photoreduction was performed on a well-known $\mathrm{Re}\left(\right.$ bpy) $(\mathrm{CO})_{3} \mathrm{Cl}$ (bpy $=2,2^{\prime}$-bipyridine) photocatalyst. It was synthesized according to the literature. ${ }^{24,25}$ Three different batches were prepared for the current experiments. Briefly, in a $100 \mathrm{~mL}$ round-bottom flask, $\mathrm{Re}(\mathrm{CO})_{5} \mathrm{Cl}(0.50 \mathrm{~g}, 1.35 \mathrm{mmol})$, 2,2'-bipyridine $(0.21 \mathrm{~g}, 1.35 \mathrm{mmol})$, and toluene $(50 \mathrm{~mL})$ were added together, and the resultant reaction mixture was heated under refluxing conditions for $5 \mathrm{~h}$. Upon cooling, the product was filtered under vacuum, and rinsed with cold toluene. ${ }^{1} \mathrm{H}$ NMR ( $\delta, 400 \mathrm{MHz}$, DMSO-d6): $9.01\left(\mathrm{~d},{ }^{1} \mathrm{H}\right), 8.75\left(\mathrm{~d},{ }^{1} \mathrm{H}\right)$, 8.35(t, $\left.{ }^{1} \mathrm{H}\right), 7.77\left(\mathrm{t},{ }^{1} \mathrm{H}\right)$.

\subsection{Conditions of the photocatalytic tests using the new FTIR in situ reactor}

In this work, the reactor was used in agitated slurry mode where the catalyst was already dispersed as detailed below for the different photocatalytic tests performed in this study.

\section{Anaerobic photocatalytic decomposition of Formic acid}

A typical experiment for the batch operation mode of in situ reactor was performed as follows: $20 \mathrm{mg}$ of $\mathrm{TiO}_{2} \mathrm{P} 25$ were dispersed in $10 \mathrm{~mL}$ of acetonitrile $(\mathrm{AcN})$ or water with $1 \mathrm{mM}$ of formic acid. The reaction mixture was sonicated for 30 minutes. Afterward, the mixture was bubbled with argon for $30 \mathrm{~min}$ to ensure an inert atmosphere. The monochromatic irradiation (at $365 \mathrm{~nm}$ ) of the samples were performed. IR spectra of the reactor headspace were recorded using Nicolet 6700 IR spectrometer (Thermo Fisher Scientific) equipped with an MCT detector. The spectra were recorded at 128 scans with a spectral resolution of $4 \mathrm{~cm}^{-1}$ and a time resolution of $2 \mathrm{~min} / \mathrm{spectrum}$. After 15 $\mathrm{h}$ of irradiation, the reaction is stopped, and an injection of the gases produced in the reactor is taken and injected in the GC to determine the concentrations of hydrogen and for a double check of the $\mathrm{CO}_{2}$ and $\mathrm{CO}$ produced during the reaction. The experiments were repeated three times and the error was estimated to $10 \%$.

\section{Photodegradation of Methylene Blue (MB)}


$50 \mathrm{mg}$ of $\mathrm{TiO}_{2}(\mathrm{P} 25)$ was dispersed in $50 \mathrm{~mL}$ of distilled water $(\mathrm{pH} \approx 6)$ containing $0.2 \mathrm{mM}$ of $\mathrm{MB}$. The reaction mixture was kept in dark for a given time (15-30 min) and sonicated for 30 minutes to obtain a homogeneous suspension of $\mathrm{TiO}_{2}$. Then, the mixture was agitated during $1 \mathrm{~h}$ by a magnetic stirrer before irradiation in order to ensure the adsorption-desorption equilibrium. The samples were then irradiated with a Xe-Hg lamp (with a $365 \mathrm{~nm}$ pass filter; $15 \mathrm{~mW} / \mathrm{cm}^{2}$ ). $2 \mathrm{~mL}$ aliquots were taken and filtered, to remove the solid particles, at different reaction time and analyzed by transmission UV-vis spectroscopy (Cray 4000 UV-vis spectrophotometer) using a quartz cuvette of $1 \mathrm{~cm}$ of path length. The concentration of MB was measured by using the absorbance of the characteristic bands at $661 \mathrm{~nm}$ and at $293 \mathrm{~nm}$. The gas headspace of the reaction was analyzed using FTIR with the same condition and parameter mentioned above.

\section{Photocatalytic reduction of $\mathrm{CO}_{2}$}

The photocatalytic $\mathrm{CO}_{2}$ reduction was tested in the new in situ reactor using $\mathrm{Re}(\mathrm{bpy})(\mathrm{CO})_{3} \mathrm{Cl}(1 \mathrm{mM})$ as a photocatalyst, in presence of TEOA $(0.1 \mathrm{M})$ as electron donor dissolved in AcN/ $\mathrm{H}_{2} \mathrm{O}$ mixture $(10 / 1.8 \mathrm{~mL})$. The solution was sonicated for $30 \mathrm{~min}$ at room temperature and bubbled with argon and then with $\mathrm{CO}_{2}$ for $30 \mathrm{~min}$ with a flow rate of $20 \mathrm{~mL} / \mathrm{min}$. As a light source, Xe-lamp (LC8 Hamamatsu, $200 \mathrm{~W}$ ) with pass-high filter at $390 \mathrm{~nm}$ was used. The headspace of the reaction was analyzed using FTIR with the same condition and parameter mentioned above. At the end of the reaction, the headspace products were analyzed and measured by gas chromatography as detailed previously.

\section{RESULTS AND DISCUSSION}

Calibration of the reactor with $\mathrm{CO}_{2}, \mathrm{CO}$ and $\mathrm{H}_{2} . \mathrm{CO}, \mathrm{CO}_{2}$, and $\mathrm{H}_{2}$ are the main products investigated from the photocatalytic tests performed in this work. In general, $\mathrm{CO}$ and $\mathrm{CO}_{2}$ are very often the final products of the $\mathrm{CO}_{2}$ photoreduction (in the liquid phase) and photocatalytic purification of water. Therefore, the quantitative analysis of these gases in real time is of a high importance. In some reactions, $\mathrm{H}_{2}$ is also present as a coproduct (with others such as $\mathrm{CO}_{2}$ and $\mathrm{CO}$ ) especially for $\mathrm{CO}_{2}$ photoreduction and photocatalytic decomposition of some products as formic acid. Since $\mathrm{H}_{2}$ is not detectable by IR, its calibration was only performed by the GC. Consequently, for some experiments realized in this work, the FTIR and GC techniques are complementary, and allowed confirming the results obtained by IR.

The gas calibrations were performed in flow mode and the IR reactor was connected to gas lines with gas mixing devices and mass flow controllers. The evolution of the GC bands and IR bands intensity of $\mathrm{CO}$ and $\mathrm{CO}_{2}$ versus their concentrations in the gas phase are presented in Figure 1 (Ar was used as a carrier gas). For $\mathrm{H}_{2}$ the results are reported in the supplementary information (Figure S1). More details on the IR spectra resolution and on the GC analysis are detailed in the experimental section. Linear evolution of the IR and GC signal can be observed for different products, with an error lower than $10 \%$ and " $R$ " values higher than 0.98 . This is comparable with the error obtained by the GC technique with an error value around $15 \%$. It also confirms the reactor sealing which is also proved by the stability of the intensity of the corresponding IR bands during more than two hours at a given concentration in a batch mode. The determined equation between the concentration, the IR band area and
GC peak intensity is then used for calculating the amount of the detectable gas products of our photocatalytic tests performed with this reactor under similar conditions.

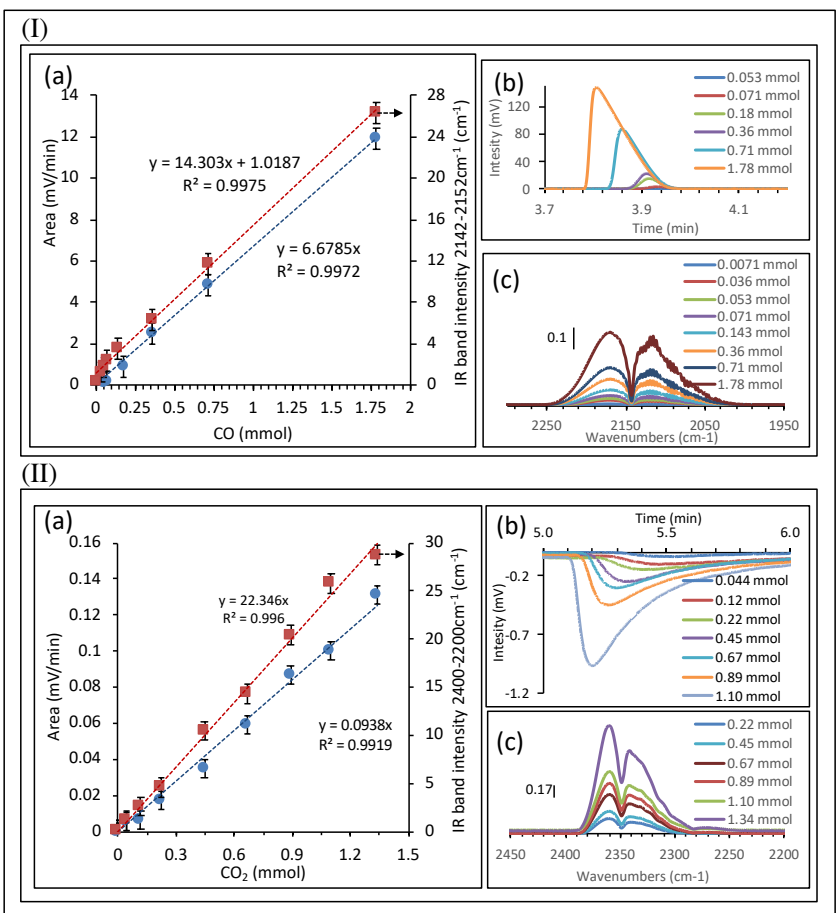

Figure 1. $\mathrm{CO}$ (I-a) and $\mathrm{CO}_{2}$ (II-a) calibration curves as determined by GC (circle; left scale) and FTIR (square; right scale) for the new in situ reactor. (b) and (c) are the corresponding GC peaks and characteristic IR bands of the $\mathrm{CO}$ (I) and $\mathrm{CO}_{2}$ (II) in Ar vs. concentration, respectively. GC parameters: (I) column: MolSive5 A; inlet temperature $=423 \mathrm{~K}$; column temperature: $393 \mathrm{~K}$ (for $\mathrm{H}_{2}$ and $\mathrm{CO}$ ) and $523 \mathrm{~K}$ (for $\mathrm{CO}_{2}$ ); carrier gas: $\mathrm{He}$ (for $\mathrm{CO}$ ) and $\mathrm{N}_{2}$ (for $\mathrm{CO}_{2}$ ); split flow rate $=60 \mathrm{~mL} / \mathrm{min}$; split ratio $=1 / 12$; injected volume: $1 \mathrm{~mL}$.

\section{Photocatalytic tests}

Photocatalytic decomposition of Formic acid (FAc) on $\mathrm{TiO}_{2}$. The dehydrogenation of FAc (Scheme 2-1) offers an efficient route for hydrogen generation and storage (in a chemical form) and thus attracts tremendous interest lately. ${ }^{26-34} \mathrm{Nev}$ ertheless, the dehydration of the FAc during its catalytic decomposition must be avoided to prevent the catalyst poisoning by $\mathrm{CO}$ in the fuel cells (Scheme 2-2). Civis el al. already studied this reaction using ex-situ FTIR spectroscopy. $\mathrm{CO}_{2}$ and $\mathrm{CO}$ were detected as final products. ${ }^{35}$ In this work, in situ FTIR reactor was used to monitor the $\mathrm{CO}_{2}$ and $\mathrm{CO}$ production during the photocatalytic decomposition of formic acid on $\mathrm{TiO}_{2}-\mathrm{P} 25$. Figure 2 demonstrates the evolution of the $\mathrm{CO}_{2}$ and $\mathrm{CO}$ versus the irradiation time. The formation of the $\mathrm{CO}_{2}$ is mainly related to the production of hydrogen while the $\mathrm{CO}$ is the product of the dehydration of formic acid.

$$
\begin{array}{ll}
\mathrm{HCOOH} \rightarrow \mathrm{CO}_{2}+\mathrm{H}_{2} & \text { (1) } \\
\mathrm{HCOOH} \rightarrow \mathrm{CO}+\mathrm{H}_{2} \mathrm{O} & \text { (2) }
\end{array}
$$

Scheme 2. The two possible pathways of the photocatalytic decomposition of formic acid under anaerobic condition: (1) dehydrogenation and (2) dehydration. 


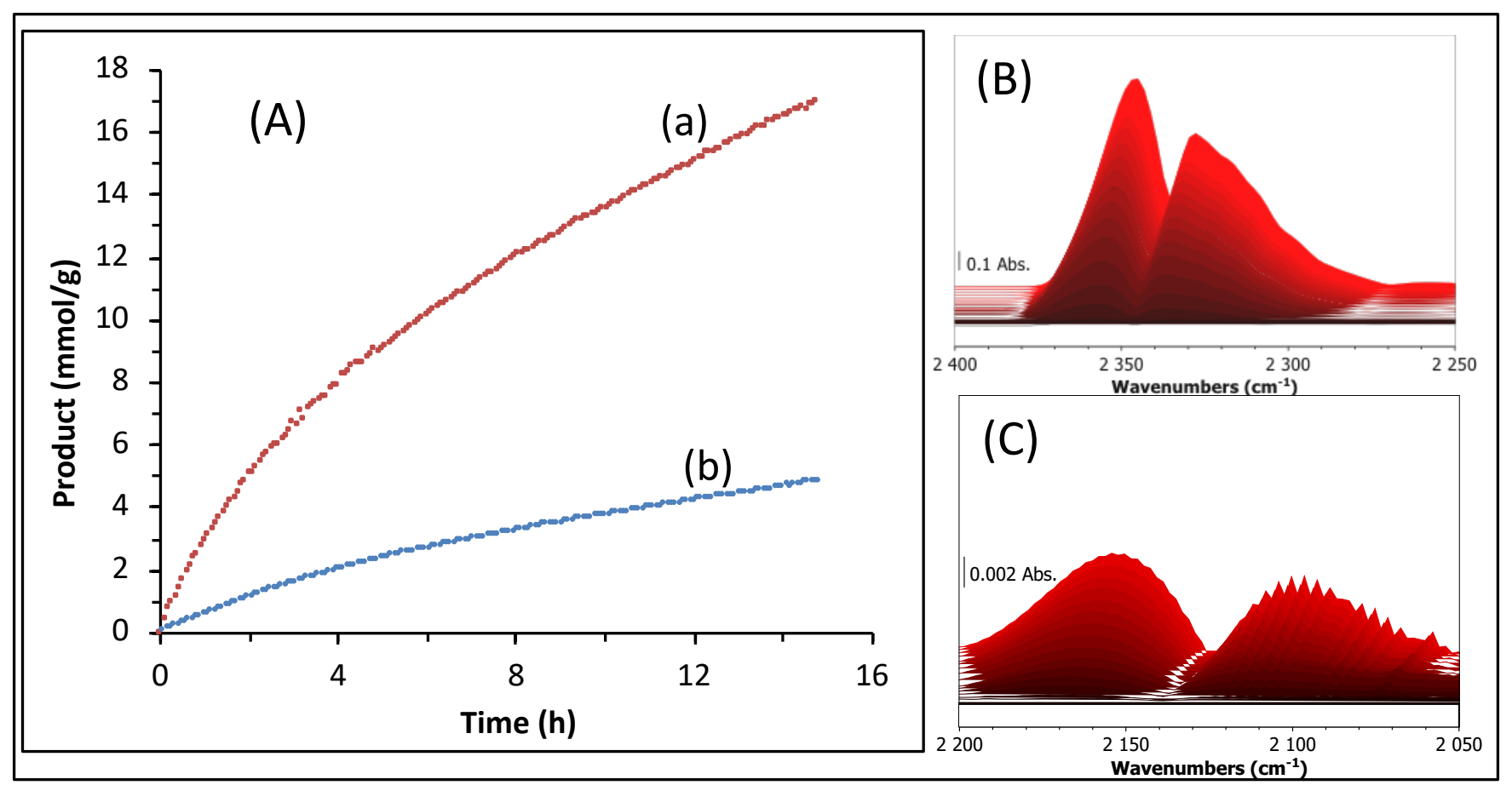

Figure 2. (A) Evolution of the $\mathrm{CO}_{2}$ (a) and $\mathrm{CO}$ (b) versus the time (in mmol per gram of photocatalyst) during the photocatalytic decomposition of $\mathrm{HCOOH}$ in water over $\mathrm{TiO}_{2}-\mathrm{P} 25$ under monochromatic $\mathrm{UV}$ irradiation (at $365 \mathrm{~nm} ; 15 \mathrm{~mW} / \mathrm{cm}^{2}$ ). The amount was calculated by the integration of (B) the characteristic $\mathrm{CO}_{2}$ and (C) $\mathrm{CO}$ IR bands area basing on the calibration curves (error $\approx 10 \%$ ). Time resolution= 2 $\mathrm{min} / \mathrm{spectrum}$; Reaction condition: $[\mathrm{HCOOH}]=1 \mathrm{mM}$; Total volume $=10 \mathrm{~mL} ; \mathrm{m}_{\mathrm{TiO} 2}=20 \mathrm{mg}$; Irradiance $=15 \mathrm{~mW} / \mathrm{cm}^{2} ;$ Temperature $=298$ $303 \mathrm{~K}$; Ar atmosphere.

The quantity of headspace gas products obtained by in situ FTIR is confirmed by the GC analysis performed at the end of the reaction. The similar amount of $\mathrm{CO}_{2}$ and $\mathrm{CO}$ detected by FTIR and GC analyses (Figure 3 (A)), demonstrate the credibility of the in situ FTIR technique used in this work. In addition, the amount of $\mathrm{H}_{2}$ is very close to that of produced $\mathrm{CO}_{2}$ which is in agreement with the decomposition reaction. The selectivity of the dehydrogenation process (based on $\mathrm{CO}_{2}$ vs $\mathrm{CO}$ selectivity) was found to be equal to $81 \pm 15 \%$ (after $15 \mathrm{~h}$ of the reaction). Following the evolution of $\mathrm{CO}_{2}$ and $\mathrm{CO}$ in real time during the reaction allows determining instantly the selectivity of the reaction as presented in Figure 3(B). A decrease of the selectivity for the photocatalytic dehydrogenation process with the time can be clearly observed. The selectivity is of $78 \%$ after $15 \mathrm{~h}$ of reaction in agreement with the value found by GC. The decrease of the $\mathrm{CO}_{2}$ selectivity can probably be assigned to the increase of the reaction $\mathrm{pH}$ due to formic acid conversion. This change in the selectivity is not important (only $5 \%$ ) to be detected by the off-line analytic techniques. In order to exclude the presence of the $\mathrm{CO}_{2}$ of the atmosphere, the experiment was reproduced under the same conditions using $\mathrm{H}^{13} \mathrm{COOH}$ isotope. The results demonstrate the selective formation of ${ }^{13} \mathrm{CO}_{2}$ (Figure S2).

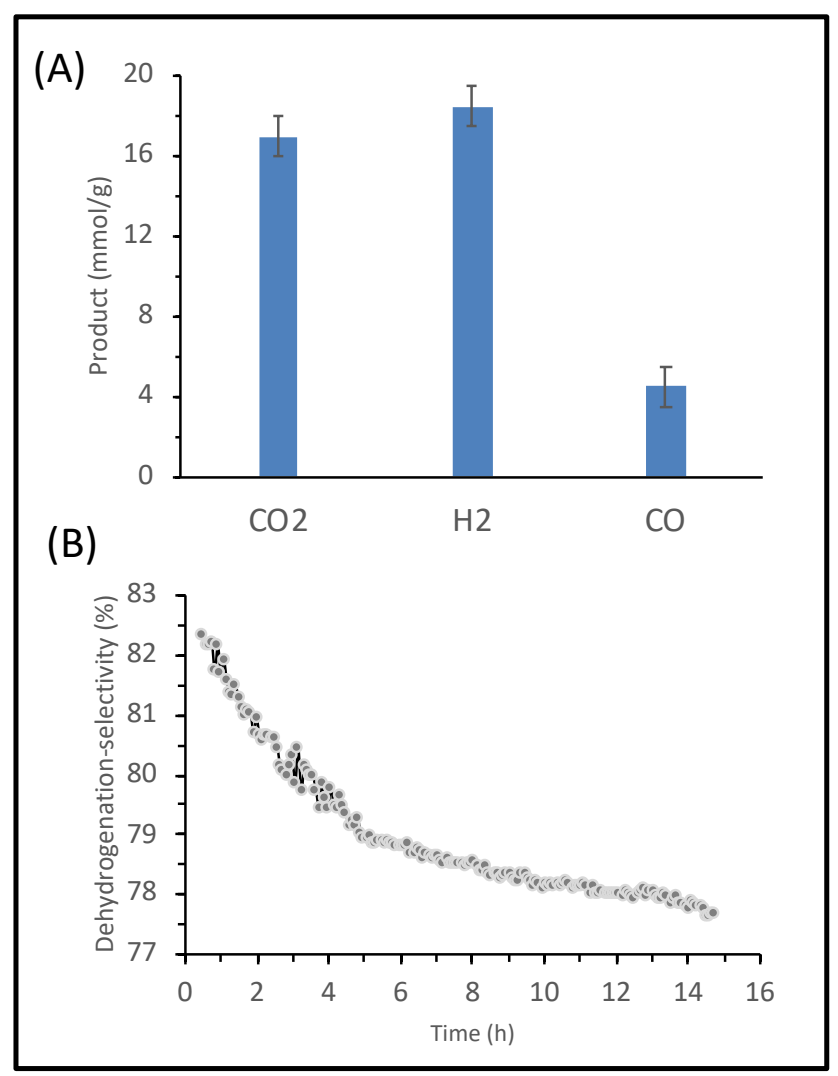

Figure 3. (A) $\mathrm{CO}_{2}, \mathrm{H}_{2}$ and $\mathrm{CO}$ amount determined by $\mathrm{GC}$ after 15 $\mathrm{h}$ of irradiation. (B) evolution of the dehydrogenation selectivity versus the irradiation time. 
The same reaction has been performed under polychromatic $\mathrm{UV}$-irradiation (irradiance $\approx 205 \mathrm{~mW} / \mathrm{cm}^{2}$ ) for 2 hours and then the irradiation was stopped suddenly for more than $16 \mathrm{~h}$. The in situ FTIR analysis demonstrates an important and linear increase of the $\mathrm{CO}_{2}$ under irradiation (Figure S3). However, no evolution of the $\mathrm{CO}_{2}$ was observed in dark demonstrating the photocatalytic behavior of the reaction. The high stability of the IR band intensity of $\mathrm{CO}_{2}$ (for more than 16 hours) demonstrates the good sealing of the reactor for a relatively long-time reaction (more than 24 hours for the reaction in aqueous solutions). This sealing is important for a rigorous quantification of the products, and, furthermore, for the stability of the catalyst in case of sensitivity toward $\mathrm{O}_{2}$ or other atmospheric gases.

Photodegradation of Methylene Blue on $\mathrm{TiO}_{2}$. Dyes and other organic compounds are the major pollutants of water and coming mainly from industries. These water pollutants pose environmental hazards to human, aquatic animals and microorganisms. Advanced oxidation processes (AOP) are usually used for waste water purification. Among the AOP methods, heterogeneous photocatalysis appears as an emerging destructive technology leading to the total mineralization of most of the organic pollutants in wastewater. ${ }^{36-38}$ Methylene Blue is one of the mostly used as a dye model for studying the photocatalytic activity of dyes photodegradation..$^{39-40}$ This is revealed by more than hundreds of papers published each year on the photocatalytic degradation of Methylene Blue (Figure S4). In general, different experimental techniques are used for both qualitative and quantitative analyses of dyes. Among these techniques, the UV-visible spectroscopy is the mostly used due to the high absorbance of dyes in the visible range. Therefore, the degradation of these hazardous compounds is studied by following their absorbance bands. However, the decrease of the characteristic absorbance bands cannot be used as a prove for a total degradation and/or oxidation (conversion to $\mathrm{CO}_{2}$ ). Consequently, the new in situ FTIR reactor is very appropriate and convenient for ensuring the total photooxidation of the hazardous compounds or not.

The photodegradation of $\mathrm{MB}$ on $\mathrm{TiO}_{2}-\mathrm{P} 25$ has been studied as detailed in the experimental section. The evolution of the MB photodegradation was investigated by UV-visible spectroscopy and the results are reported in Figure 4A. The degradation of the $\mathrm{MB}$ was calculated using the intensities of its characteristic absorbance bands at $661 \mathrm{~nm}$ and $293 \mathrm{~nm}$ (inset Figure 4A). ${ }^{41} \mathrm{~A}$ total discoloration of the solution can be observed after only 40 min of monochromatic irradiation at $365 \mathrm{~nm}$ of $\mathrm{TiO}_{2}-\mathrm{P} 25$ suspension. However, the FTIR results (Figure 4B) shows a linear increase of the $\mathrm{CO}_{2}$ until $125 \mathrm{~min}$. This mean after $85 \mathrm{~min}$ of the total discoloration of MB. After that a plateau is observed and a total oxidation of MB can be expected. N.B. for confirming this hypothesis, a determination of total organic carbon content (TOC) in the MB solution is required. Furthermore, the rate of the $\mathrm{CO}_{2}$ production is slower than that of the MB degradation. This is probably assigned to the formation of sub-products undetectable by UV where their oxidation is relatively slow. In conclusion, the in situ FTIR was crucial to investigate the possible complete photooxidation. Following the photodegradation based only on the UV-visible spectra is unfortunately not enough for proving the total depollution of water.

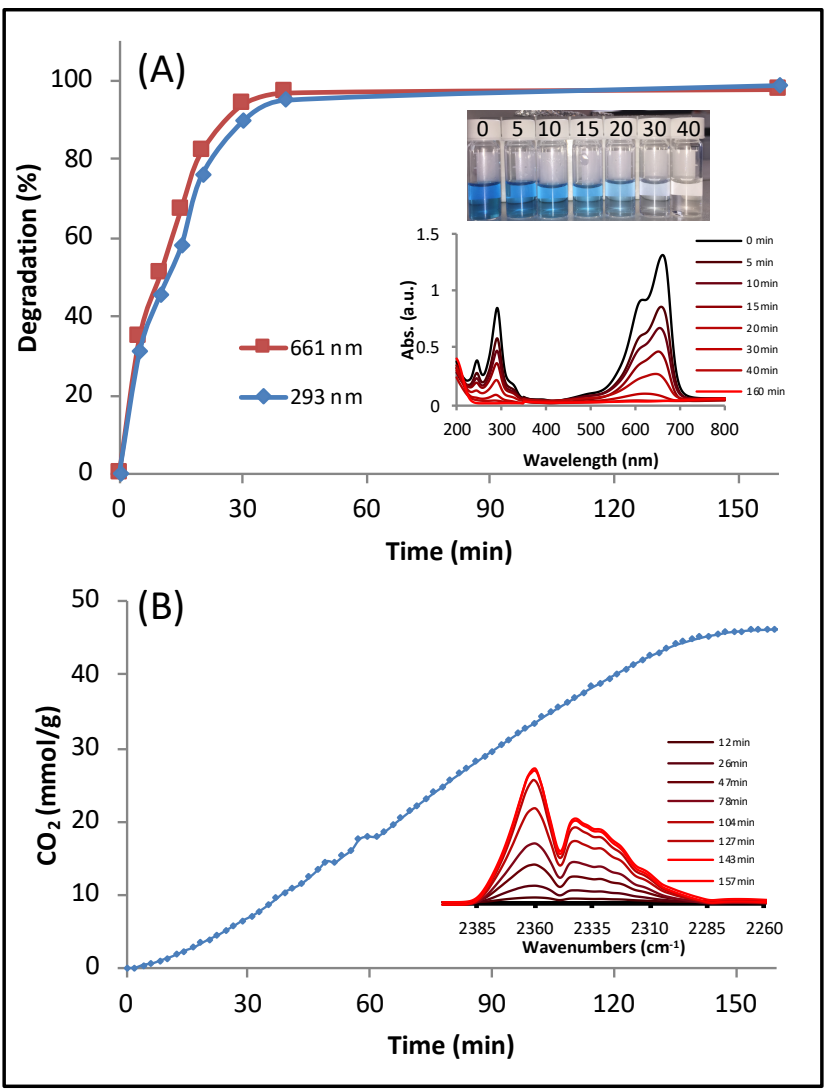

Figure 4. (A) The evolution of the photocatalytic degradation of $\mathrm{MB}$ on $\mathrm{TiO}_{2}-\mathrm{P} 25$ versus the irradiation time. Inset: the corresponding samples and their UV-visible spectra. (B) The evolution of the $\mathrm{CO}_{2}$ in the gas headspace. Inset: the FTIR spectra of the headspace in the vibration region of $\mathrm{CO}_{2}$ at different irradiation time. Reaction conditions: $\mathrm{m}_{\mathrm{TiO}_{2}}=50 \mathrm{mg} ; \mathrm{V}_{\text {water }}=50 \mathrm{~mL} ;[\mathrm{MB}]=0.2 \mathrm{mM}$; Lamp $\mathrm{Xg}-\mathrm{Xe} ; \lambda=365 \mathrm{~nm}$; irradiance $=15 \mathrm{~mW} / \mathrm{cm}^{2}$.

$\mathrm{CO}_{2}$ photoreduction on $\mathrm{Re}(\mathrm{bpy})(\mathrm{CO})_{3} \mathrm{Cl}$. The photocatalytic reduction of carbon dioxide has attracted great attention during the last years. It is an important component of artificial photosynthesis, prompted by the concerns of increasing concentrations of this greenhouse gas in the atmosphere. ${ }^{42}$ Valuable gas and volatile organic compounds such as $\mathrm{CO}, \mathrm{CH}_{3} \mathrm{OH}, \mathrm{CH}_{4}$, $\mathrm{C}_{2} \mathrm{H}_{4}$, etc., are detected as main products of the (photo/electro) catalytic reduction of $\mathrm{CO}_{2}{ }^{43}$ Among the catalysts for $\mathrm{CO}_{2}$ reduction, $\operatorname{Re}($ bpy $)(\mathrm{CO})_{3} \mathrm{Cl}\left(1\right.$, bpy $=2,2^{\prime}$-bipyridine $)$ and its derivatives have been recognized as being very active and selective for the reduction of $\mathrm{CO}_{2}$ to $\mathrm{CO}^{44-52}$ In our study, $\mathrm{Re}(\mathrm{bpy})(\mathrm{CO})_{3} \mathrm{Cl}$ is selected as photocatalyst to monitor the production of $\mathrm{CO}$ by in situ FTIR during the $\mathrm{CO}_{2}$ photoreduction under similar conditions reported above in the literature (see the experimental section).

The results are presented in Figure 5. A linear increase of the $\mathrm{CO}$ amount versus the visible irradiation time can be observed (Figure 5A-B). The GC analysis of the headspace gas products after $12 \mathrm{~h}$ of irradiation agrees with the quantity detected by the in situ FTIR for the same time of irradiation (Figure 5C). The increase of the $\mathrm{CO}$ production demonstrates that there is no deactivation of the photocatalyst even after $12 \mathrm{~h}$ of reaction. Therefore, once again the new in situ FTIR can clearly serves to such kind of reaction. It allows not only following the kinetic of the $\mathrm{CO}$ production (and other gas or VOC) with high precision and simplicity, but also monitoring the stability of the photocatalyst along the reaction. 


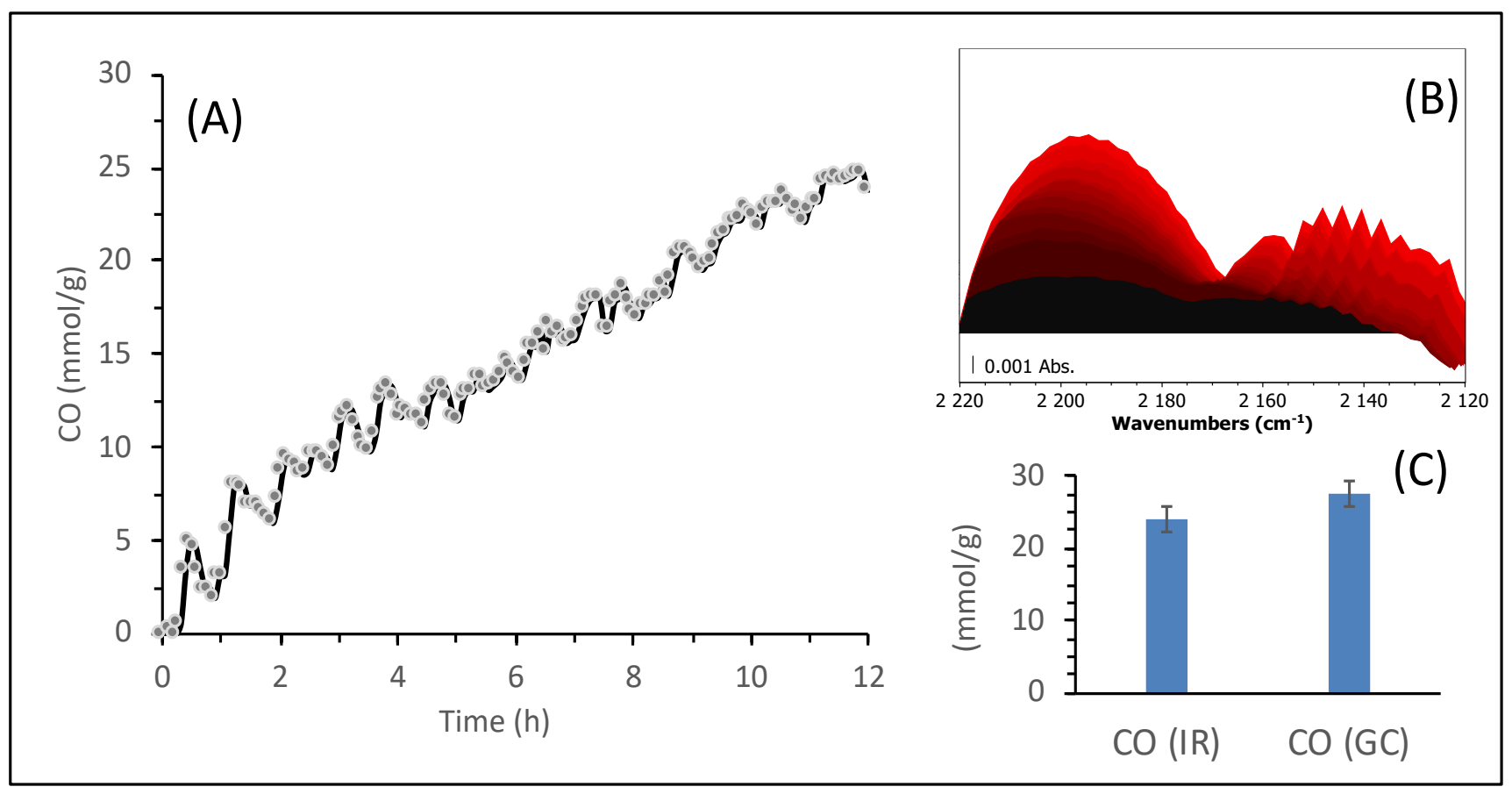

Figure 5. (A) Evolution of the $\mathrm{CO}$ gas production versus the visible irradiation time using $\mathrm{Re}(\mathrm{bpy})(\mathrm{CO})_{3} \mathrm{Cl}$ as photocatalyst. (B) Evolution of the CO IR bands during the reaction (time resolution $=5 \mathrm{~min} /$ spectrum). (C) Amount of the CO produced after $12 \mathrm{~h}$ of the photocatalytic reaction as determined by in situ FTIR and by GC analysis of the gas headspace. Reaction conditions: $10 \mathrm{~mL}$ of $\mathrm{ACN}$; $1.8 \mathrm{~mL}$ of $\mathrm{H}_{2} \mathrm{O}$; $\left[\mathrm{Re}(\mathrm{bpy})(\mathrm{CO})_{3} \mathrm{Cl}\right]=1 \mathrm{mM} ;[\mathrm{TEOA}]=0.1 \mathrm{M}$; bubbled with $\mathrm{CO}_{2}$ for $30 \mathrm{~min}$ with a flow rate of $20 \mathrm{~mL} / \mathrm{min}$. Irradiance= $\mathrm{UV}-\mathrm{V}$ is irradiation (at $390 \mathrm{~nm}$ ); room temperature; under Ar atmosphere.

\section{CONCLUSION}

In this work, we have developed and tested a new in situ FTIR reactor for monitoring the gas headspace of a liquid reaction. This reactor can be very useful for studying homogeneous and heterogenous catalytic and photocatalytic reactions, performed at relatively low temperatures and giving rise to gaseous products detectable by FTIR. The new reactor has been tested in three different model reactions widely studied in photocatalysis: photocatalytic decomposition of Formic acid, photodegradation of Methylene Blue and $\mathrm{CO}_{2}$ photoreduction. It allowed a real time monitoring of the $\mathrm{CO}_{2}$ and $\mathrm{CO}$ produced from these reactions and gave rise to quantitative results with high precision. The reproducibility of the experiments was tested and errors were estimated to be lower than $10 \%$. The results were confirmed by gas chromatography. For the formic acid, a low decrease of the selectivity (of about $5 \%$ ) with time was observed and assigned to $\mathrm{pH}$ modification due to FAc decomposition. The non-significant modification of the selectivity makes challenging its observation by ex-situ analysis. For Methylene Blue, the in situ FTIR shows that the total oxidation is 3 times slower than MB degradation. Moreover, the photocatalyst is not deactivated during $\mathrm{CO}_{2}$ photoreduction as a linear increase is observed during the reaction (12h). The new setup is easy to handle, to ship, and is very efficient which makes it very suitable for performing fast and/or preliminary studies.

\section{ASSOCIATED CONTENT}

\section{Supporting Information}

The following data are available free of charge on the ACS Publications website as Supporting Information: The FTIR setup used for monitoring the gas headspace of a photocatalytic reaction in liquid phase. The picture of the reactor and its available and removable accessories. The calibration curves of $\mathrm{H}_{2}$ as determined by GC using the new in situ reactor. The IR spectra in the region of the $\mathrm{CO}_{2}$ vibration of gas headspace of the $\mathrm{H}^{12} \mathrm{COOH}$ and $\mathrm{H}^{13} \mathrm{COOH}$ after $\mathrm{UV}$-irradiation in presence of $\mathrm{TiO}_{2} \mathrm{P} 25$. The evolution of the amount of the $\mathrm{CO} 2$ produced during the photocatalytic dehydrogenation of formic acid on $\mathrm{TiO}_{2}$ under polychromatic UV irradiation and in dark. Number of papers appeared per year concerning the photocatalytic degradation of Methylene Blue. Source: web of knowledge.

\section{AUTHOR INFORMATION}

\section{Corresponding Author}

*E-mail: mohamad.elroz@ensicaen.fr

\section{Author Contributions}

The manuscript was written through contributions of all authors. All authors have given approval to the final version of the manuscript.

\section{ACKNOWLEDGMENT}

M. El-Roz acknowledges the Region Normandie (RAPHYD project) and the FEDER (Sirco project) for the financial support.

\section{REFERENCES}

(1) Ola, O.; Maroto-Valer, M. M. Review of Material Design and Reactor Engineering on $\mathrm{TiO}_{2}$ Photocatalysis for $\mathrm{CO} 2$ Reduction. $J$. Photochem. Photobiol. C Photochem. Rev. 2015, 24, 16-42.

(2) Xiong, Z.; Kuang, C.-C.; Lin, K.-Y.; Lei, Z.; Chen, X.; Gong, B.; Yang, J.; Zhao, Y.; Zhang, J.; Xia, B.; et al. Enhanced $\mathrm{CO}_{2}$ 
Photocatalytic Reduction through Simultaneously Accelerated $\mathrm{H}_{2}$ Evolution and $\mathrm{CO}_{2}$ Hydrogenation in a Twin Photoreactor. J. $\mathrm{CO}_{2}$ Util. 2018, 24 (November 2017), 500-508.

(3) Chong, M. N.; Jin, B.; Chow, C. W. K.; Saint, C. Recent Developments in Photocatalytic Water Treatment Technology: A Review. Water Res. 2010, 44 (10), 2997-3027.

(4) Borgarello, E.; Kiwi, J.; Pelizzetti, E.; Visca, M.; Grätzel, M. Photochemical Cleavage of Water by Photocatalysis. Nature 1981, 289 (5794), 158-160.

(5) Lopes, T.; Dias, P.; Andrade, L.; Mendes, A. An Innovative Photoelectrochemical Lab Device for Solar Water Splitting. Sol. Energy Mater. Sol. Cells 2014, 128, 399-410.

(6) Molinari, R.; Marino, T.; Argurio, P. Photocatalytic Membrane Reactors for Hydrogen Production from Water. Int. J. Hydrogen Energy 2014, 39 (14), 7247-7261.

(7) McCullagh, C.; Skillen, N.; Adams, M.; Robertson, P. K. J. Photocatalytic Reactors for Environmental Remediation: A Review. $J$. Chem. Technol. Biotechnol. 2011, 86 (8), 1002-1017.

(8) Maroga Mboula, V.; Héquet, V.; Gru, Y.; Colin, R.; Andrès, Y. Assessment of the Efficiency of Photocatalysis on Tetracycline Biodegradation. J. Hazard. Mater. 2012, 209-210, 355-364.

(9) Wilson, D.; Wang, W.; Lopes, R. J. G. Ceria-Doped and TiO2 Nanocomposite Coating on Multiwalled Carbon Nanotubes for the Photocatalytic Remediation of Agro-Industrial Wastewaters. Appl. Catal. B Environ. 2012, 123-124, 273-281.

(10) Galindo, C.; Jacques, P.; Kalt, A. Photodegradation of the Aminoazobenzene Acid Orange 52 by Three Advanced Oxidation Processes: $\mathrm{UV} / \mathrm{H}_{2} \mathrm{O}_{2}, \mathrm{UV} / \mathrm{TiO}_{2}$ and $\mathrm{VIS} / \mathrm{TiO}_{2}$. J. Photochem. Photobiol. A Chem. 2000, 130 (1), 35-47.

(11) Besson, M.; Gallezot, P.; Pinel, C. Conversion of Biomass into Chemicals over Metal Catalysts. Chem. Rev. 2014, 114 (3), 1827 1870 .

(12) Mäki-Arvela, P.; Holmbom, B.; Salmi, T.; Murzin, D. Y. Recent Progress in Synthesis of Fine and Specialty Chemicals from Wood and Other Biomass by Heterogeneous Catalytic Processes. Catal. Rev. 2007, 49 (3), 197-340.

(13) Mul, G.; Hamminga, G. M.; Moulijn, J. A. Operando ATRFTIR Analysis of Liquid-Phase Catalytic Reactions: Can Heterogeneous Catalysts Be Observed? Vib. Spectrosc. 2004, 34 (1), 109-121.

(14) Meemken, F.; Müller, P.; Hungerbühler, K.; Baiker, A. Simultaneous Probing of Bulk Liquid Phase and Catalytic Gas-LiquidSolid Interface under Working Conditions Using Attenuated Total Reflection Infrared Spectroscopy. Rev. Sci. Instrum. 2014, 85 (8), 084101.

(15) Cassano, A. E.; Alfano, O. M. Reaction Engineering of Suspended Solid Heterogeneous Photocatalytic Reactors. Catal. Today 2000, 58 (2-3), 167-197.

(16) Hauchecorne, B.; Tytgat, T.; Terrens, D.; Vanpachtenbeke, F.; Lenaerts, S. Validation of a Newly Developed FTIR in Situ Reactor: Real Time Study of Photocatalytic Degradation of Nitric Oxide. Infrared Phys. Technol. 2010, 53 (6), 469-473.

(17) Schneider, M. S.; Grunwaldt, J. D.; Bürgi, T.; Baiker, A. High Pressure View-Cell for Simultaneous in Situ Infrared Spectroscopy and Phase Behavior Monitoring of Multiphase Chemical Reactions. Rev. Sci. Instrum. 2003, 74 (9), 4121-4128.

(18) Zaera, F. New Advances in the Use of Infrared Absorption Spectroscopy for the Characterization of Heterogeneous Catalytic Reactions. Chem. Soc. Rev. 2014, 43 (22), 7624-7663.

(19) El-Roz, M.; Bazin, P.; Birsa Čelič, T.; Zabukovec Logar, N.; Thibault-Starzyk, F. Pore Occupancy Changes Water/Ethanol Separation in a Metal-Organic Framework-Quantitative Map of Coadsorption by IR. J. Phys. Chem. C 2015, 119 (39), 22570-22576.

(20) El-Roz, M.; Bazin, P.; Daturi, M.; Thibault-Starzyk, F. On the Mechanism of Methanol Photooxidation to Methylformate and Carbon Dioxide on $\mathrm{TiO}_{2}$ : An Operando-FTIR Study. Phys. Chem. Chem. Phys. 2015, 17 (17), 11277-11283.

(21) El-Roz, M.; Bazin, P.; Daturi, M.; Thibault-Starzyk, F. Operando Infrared (IR) Coupled to Steady-State Isotopic Transient Kinetic Analysis (SSITKA) for Photocatalysis: Reactivity and Mechanistic Studies. ACS Catal. 2013, 3 (12), 2790-2798.
(22) El-Roz, M.; Kus, M.; Cool, P.; Thibault-Starzyk, F. New Operando IR Technique to Study the Photocatalytic Activity and Selectivity of $\mathrm{TiO}_{2}$ nanotubes in Air Purification: Influence of Temperature, UV Intensity, and VOC Concentration. J. Phys. Chem. C 2012, $116(24), 13252-13263$.

(23) Henych, J.; Štengl, V.; Mattsson, A.; Österlund, L. In Situ FTIR Spectroscopy Study of the Photodegradation of Acetaldehyde and Azo Dye Photobleaching on Bismuth-Modified TiO 2. Photochem. Photobiol. 2015, 91 (1), 48-58.

(24) Smieja, J. M.; Kubiak, C. P. Re(Bipy$\mathrm{TBu})(\mathrm{CO})_{3} \mathrm{Cl}$-improved Catalytic Activity for Reduction of Carbon Dioxide: IR-Spectroelectrochemical and Mechanistic Studies. Inorg. Chem. 2010, 49 (20), 9283-9289.

(25) Schneider, T. W.; Ertem, M. Z.; Muckerman, J. T.; AngelesBoza, A. M. Mechanism of Photocatalytic Reduction of $\mathrm{CO}_{2}$ by $\mathrm{Re}(\mathrm{Bpy})(\mathrm{CO})_{3} \mathrm{Cl}$ from Differences in Carbon Isotope Discrimination. ACS Catal. 2016, 6 (8), 5473-5481.

(26) Celaje, J. J. A.; Lu, Z.; Kedzie, E. A.; Terrile, N. J.; Lo, J. N.; Williams, T. J. A Prolific Catalyst for Dehydrogenation of Neat Formic Acid. Nat. Commun. 2016, 7 (7), 11308.

(27) Wen, M.; Mori, K.; Kuwahara, Y.; Yamashita, H. Plasmonic $\mathrm{Au}$ @Pd Nanoparticles Supported on a Basic Metal-Organic Framework: Synergic Boosting of $\mathrm{H}_{2}$ Production from Formic Acid. ACS Energy Lett. 2017, 2 (1), 1-7.

(28) Cheng, J.; Gu, X.; Liu, P.; Wang, T.; Su, H. Controlling Catalytic Dehydrogenation of Formic Acid over Low-Cost Transition Metal-Substituted AuPd Nanoparticles Immobilized by Functionalized Metal-Organic Frameworks at Room Temperature. J. Mater. Chem. A 2016, 4 (42), 16645-16652.

(29) Gazsi, A.; Schubert, G.; Pusztai, P.; Solymosi, F. Photocatalytic Decomposition of Formic Acid and Methyl Formate on TiO2 Doped with $\mathrm{N}$ and Promoted with Au. Production of $\mathrm{H}_{2}$. Int. J. Hydrogen Energy 2013, 38 (19), 7756-7766.

(30) Halasi, G.; Schubert, G.; Solymosi, F. Photolysis of $\mathrm{HCOOH}$ over Rh Deposited on Pure and N-Modified $\mathrm{TiO}_{2}$ : Production of Pure $\mathrm{H}_{2}$. Catal. Letters 2012, 142 (2), 218-223.

(31) Chiarello, G. L.; Aguirre, M. H.; Selli, E. Hydrogen Production by Photocatalytic Steam Reforming of Methanol on Noble MetalModified $\mathrm{TiO}_{2}$. J. Catal. 2010, 273 (2), 182-190.

(32) Chen, T.; Wu, G.; Feng, Z.; Hu, G.; Su, W.; Ying, P.; Li, C. In Situ FT-IR Study of Photocatalytic Decomposition of Formic Acid to Hydrogen on $\mathrm{Pt} / \mathrm{TiO}_{2}$ Catalyst. Chinese J. Catal. 2008, 29 (2), 105107.

(33) Liao, L. F.; Wu, W. C.; Chen, C. Y.; Lin, J. L. Photooxidation of Formic Acid vs Formate and Ethanol vs Ethoxy on TiO2and Effect of Adsorbed Water on the Rates of Formate and Formic Acid Photooxidation. J. Phys. Chem. B 2001, 105 (32), 7678-7685.

(34) Araña, J.; Garriga i Cabo, C.; Doña-Rodríguez, J. M.; González-Díaz, O.; Herrera-Melián, J. A.; Pérez-Peña, J. FTIR Study of Formic Acid Interaction with $\mathrm{TiO}_{2}$ and $\mathrm{TiO}_{2}$ Doped with $\mathrm{Pd}$ and $\mathrm{Cu}$ in Photocatalytic Processes. Appl. Surf. Sci. 2004, 239 (1), 60-71.

(35) Civiš, S.; Ferus, M.; Zukalová, M.; Kubát, P.; Kavan, L. Photochemistry and Gas-Phase FTIR Spectroscopy of Formic Acid Interaction with Anatase $\mathrm{Ti}_{18 \mathrm{O}_{2}}$ Nanoparticles. J. Phys. Chem. C 2012, $116(20), 11200-11205$.

(36) Lachheb, H.; Puzenat, E.; Houas, A.; Ksibi, M.; Elaloui, E.; Guillard, C.; Herrmann, J.-M. Photocatalytic Degradation of Various Types of Dyes (Alizarin S, Crocein Orange G, Methyl Red, Congo Red, Methylene Blue) in Water by UV-Irradiated Titania. Appl. Catal. B Environ. 2002, 39 (1), 75-90.

(37) Han, F.; Kambala, V. S. R.; Srinivasan, M.; Rajarathnam, D.; Naidu, R. Tailored Titanium Dioxide Photocatalysts for the Degradation of Organic Dyes in Wastewater Treatment: A Review. Appl. Catal. A Gen. 2009, 359 (1-2), 25-40.

(38) Akpan, U. G.; Hameed, B. H. Parameters Affecting the Photocatalytic Degradation of Dyes Using $\mathrm{TiO}_{2}$-Based Photocatalysts: A Review. J. Hazard. Mater. 2009, 170 (2-3), 520-529.

(39) Zhao, D.; Sheng, G.; Chen, C.; Wang, X. Enhanced Photocatalytic Degradation of Methylene Blue under Visible Irradiation on Graphene@ $\mathrm{TiO}_{2}$ Dyade Structure. Appl. Catal. B Environ. 2012, 111112, 303-308. 
(40) Zhou, B.; Zhao, X.; Liu, H.; Qu, J.; Huang, C. P. VisibleLight Sensitive Cobalt-Doped $\mathrm{BiVO}_{4}\left(\mathrm{Co}-\mathrm{BiVO}_{4}\right)$ Photocatalytic Composites for the Degradation of Methylene Blue Dye in Dilute Aqueous Solutions. Appl. Catal. B Environ. 2010, 99 (1-2), 214-221.

(41) Rauf, M. A.; Ashraf, S. S. Fundamental Principles and Application of Heterogeneous Photocatalytic Degradation of Dyes in Solution. Chem. Eng. J. 2009, 151 (1-3), 10-18.

(42) Appel, A. M.; Bercaw, J. E.; Bocarsly, A. B.; Dobbek, H.; Dubois, D. L.; Dupuis, M.; Ferry, J. G.; Fujita, E.; Hille, R.; Kenis, P. J. A.; et al. Frontiers, Opportunities, and Challenges in Biochemical and Chemical Catalysis of $\mathrm{CO}_{2}$ Fixation. Chem. Rev. 2013, 113 (8), $6621-6658$

(43) Benson, E. E.; Kubiak, C. P.; Sathrum, A. J.; Smieja, J. M. Electrocatalytic and Homogeneous Approaches to Conversion of $\mathrm{CO}_{2}$ to Liquid Fuels. Chem. Soc. Rev. 2009, 38 (1), 89-99.

(44) Hawecker, J.; Lehn, J.-M.; Ziessel, R. Photochemical and Electrochemical Reduction of Carbon Dioxide to Carbon Monoxide Mediated by $\left(2,2^{\prime}\right.$-Bipyridine)Tricarbonylchlororhenium (I) and Related Complexes as Homogeneous Catalysts. Helv. Chim. Acta 1986, 69 (8), 1990-2012.

(45) Kou, Y.; Nabetani, Y.; Masui, D.; Shimada, T.; Takagi, S.; Tachibana, H.; Inoue, H. Direct Detection of Key Reaction Intermediates in Photochemical $\mathrm{CO}_{2}$ reduction Sensitized by a Rhenium Bipyridine Complex. J. Am. Chem. Soc. 2014, 136 (16), 6021-6030.
(46) Takeda, H.; Ishitani, O. Development of Efficient Photocatalytic Systems for $\mathrm{CO}_{2}$ Reduction Using Mononuclear and Multinuclear Metal Complexes Based on Mechanistic Studies. Coord. Chem. Rev. 2010, 254 (3-4), 346-354.

(47) Ono, Y.; Tsuda, M.; Maruo, Y. Y.; Nakamura, J. Kinetic Study on $\mathrm{CO}_{2}$ Photoreduction by Re Complexes. J. Phys. Conf. Ser. 2012, 379, 012037.

(48) Hawecker, J.; Lehn, J.-M.; Ziessel, R. Electrocatalytic Reduction of Carbon Dioxide Mediated by $\operatorname{Re}(\mathrm{Bipy})(\mathrm{CO})_{3} \mathrm{Cl}$ (Bipy $=2,2^{\prime}$ Bipyridine). J. Chem. Soc., Chem. Commun. 1984, 984 (6), 328-330.

(49) Ono, Y. Effect of Substituent Groups in Rhenium Bipyridine Complexes on Photocatalytic $\mathrm{CO}_{2}$ Reduction. Am. J. Appl. Chem. 2014, 2 (5), 74.

(50) Schneider, T. W.; Ertem, M. Z.; Muckerman, J. T.; AngelesBoza, A. M. Mechanism of Photocatalytic Reduction of $\mathrm{CO}_{2}$ by $\mathrm{Re}(\mathrm{Bpy})(\mathrm{CO})_{3} \mathrm{Cl}$ from Differences in Carbon Isotope Discrimination. ACS Catal. 2016, 6 (8), 5473-5481.

(51) Sampson, M. D.; Froehlich, J. D.; Smieja, J. M.; Benson, E. E.; Sharp, I. D.; Kubiak, C. P. Direct Observation of the Reduction of Carbon Dioxide by Rhenium Bipyridine Catalysts. Energy Environ. Sci. 2013, 6 (12), 3748.

(52) Morimoto, T.; Nakajima, T.; Sawa, S.; Nakanishi, R.; Imori, D.; Ishitani, O. $\mathrm{CO}_{2}$ Capture by a Rhenium(I) Complex with the Aid of Triethanolamine. J. Am. Chem. Soc. 2013, 135 (45), 16825-16828.

\section{TOC}

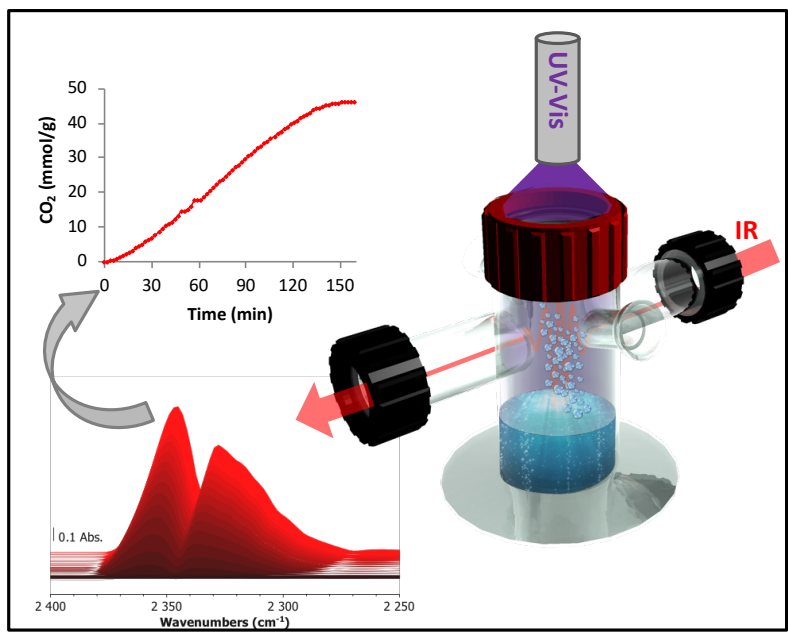

